American Journal of Applied Sciences 7 (8): 1047-1052, 2010

ISSN 1546-9239

(C) 2010 Science Publications

\title{
Synthesis and Characterization of Organotin(IV) N-Benzyl-N-Isopropyldithiocarbamate Compounds: Cytotoxic Assay on Human Hepatocarcinoma Cells (HepG2)
}

\author{
${ }^{1}$ Normah Awang, ${ }^{2}$ Ibrahim Baba, \\ ${ }^{3}$ Nor Syaidatul Akmal Mohd Yousof and ${ }^{1}$ Nurul Farahana Kamaludin \\ ${ }^{1}$ Environmental Health Programme, Faculty of Allied Health Science, \\ University Kebangsaan Malaysia, Jalan Raja Muda Abdul Aziz, 50300 Kuala Lumpur, Malaysia \\ ${ }^{2}$ Department of Chemistry, School of Chemical Sciences and Food Technology, \\ Faculty of Science and Technology, University Kebangsaan Malaysia, 43600 Bangi, Selangor, Malaysia \\ ${ }^{3}$ Department of Biomedical Science, Faculty of Allied Health Science, \\ University Kebangsaan Malaysia, Jalan Raja Muda Abdul Aziz, 50300 Kuala Lumpur, Malaysia
}

\begin{abstract}
Problem statement: Several studies on organotin(IV) dithiocarbamate compounds have been carried out but not on the synthesis and characterization together with cytotoxic assay of organotin(IV) N-benzyl-N-isopropyldithiocarbamate compounds. Approach: Three new organotin(IV) compounds of type N-benzyl-N-isopropyldithiocarbamate have been successfully synthesized by direct reaction between secondary amine with organotin(IV) chloride using in situ method. All the compounds were characterized using elemental analysis, gravimetric analysis, infrared spectroscopy and Nuclear Magnetic Resonance (NMR) spectroscopy. Results: Elemental and gravimetric analyses data of these compounds showed that agreed with the predicted formula, $\left(\mathrm{CH}_{3}\right)_{2} \mathrm{Sn}\left[\mathrm{S}_{2} \mathrm{CN}\left(\mathrm{C}_{7} \mathrm{H}_{7}\right)\left(\mathrm{i}-\mathrm{C}_{3} \mathrm{H}_{7}\right)\right]_{2}$ (1), $\left(\mathrm{C}_{4} \mathrm{H}_{9}\right)_{2} \mathrm{Sn}\left[\mathrm{S}_{2} \mathrm{CN}\left(\mathrm{C}_{7} \mathrm{H}_{7}\right)\left(\mathrm{i}-\mathrm{C}_{3} \mathrm{H}_{7}\right)\right]_{2}$ (2) and $\left(\mathrm{C}_{6} \mathrm{H}_{5}\right)_{3} \mathrm{Sn}\left[\mathrm{S}_{2} \mathrm{CN}\left(\mathrm{C}_{7} \mathrm{H}_{7}\right)\left(\mathrm{i}-\mathrm{C}_{3} \mathrm{H}_{7}\right)\right]$ (3). The infrared spectra of these compounds showed the thioureide bond, $\mathrm{v}(\mathrm{C}=\mathrm{N})$ which occurred at $1438-1440 \mathrm{~cm}^{-1}$ and the $\mathrm{v}(\mathrm{C}=\mathrm{S})$ band appeared in the range of $967-973 \mathrm{~cm}^{-1}$. The presence of the $\mathrm{v}(\mathrm{C}=\mathrm{N})$ and $\mathrm{v}(\mathrm{C}=\mathrm{S})$ bands in the infrared spectra confirmed the presence of dithiocarbamate ligand in that compounds. The bond between sulphur and tin atom were supported with the presence of peak in the range of $365-445 \mathrm{~cm}^{-1}$ that known to be as stretching mode of $v(\mathrm{Sn}-\mathrm{S})$. The most important signal in the ${ }^{13} \mathrm{C}$ NMR spectra was the chemical shift of $\mathrm{NCS}_{2}$ group. The ${ }^{13} \mathrm{C}$ NMR spectra of these compound showed a chemical shift in 195.06-202.65 ppm range, which is attributed to the carbon atom of $\mathrm{NCS}_{2}$ group. The crystal structure of compound 2 (dibutyltin(IV) N-benzyl-N-isopropyldithiocarbamate) has been determined by X-ray single crystal analysis, which shows unsymmetrical nature of the ligand towards coordination to tin. It crystallizes in triclinic P1 space group with the crystal cell parameter: $\mathrm{a}=17.7745$ (2) $(\AA), \mathrm{b}=19.5463(3)(\AA), \mathrm{c}=$ $26.2062(4)(\AA), \alpha=102.5254(7)^{\circ}, \beta=95.1492(7)^{\circ}, \gamma=110.2569(8)^{\circ}, Z=10, V\left(\AA^{3}\right)=8202.1(2)$ and $\mathrm{R}=0.028$. In addition, these compounds were screened for their cytotoxic activity on Human Hepatocarcinoma Cells (HepG2). Based on the cytotoxic activity, compounds 2 and 3 showed cytotoxic activity but compound 1 is inactive against HepG2 cells. Conclusion: The results of this study showed that the studied compounds might indeed be potential sources of anticancer agents and these would further enable us to evaluate their utility in biomedical field.
\end{abstract}

Key words: Dithiocarbamate, organotin, X-ray, cytotoxic, NMR

\section{INTRODUCTION}

Organotin(IV) compounds are extensively studied due to the applications in industrial as well as biocide properties (Gielen et al., 2000). Numerous studies on organotin(IV) compounds have been carried out in order to study its biological properties against bacterial (Jamil et al., 2009), fungus and cancer cells line (Crouse et al., 2004; Novelli et al., 1999). Several organotin compounds exhibit promising in vitro antitumor activities against human tumor cell lines (Gielen, 1996).

Corresponding Author: Normah Awang, Environmental Health Programme, Faculty of Allied Health Science, University Kebangsaan Malaysia, Jalan Raja Muda Abdul Aziz, 50300 Kuala Lumpur, Malaysia 1047 
Moreover, the biological activity of organotin(IV) dithiocarbamate compounds are greatly influenced by the structure of the molecule as well as the coordination number of the tin moiety. The search for organometallic compounds as a new alternative drug in combating human cancers has been initiated due to certain sideeffects of cis-platin and carboplatin as antitumor drugs (Mansouri-Torshizi et al., 2010; Khan et al., 2000).

In our previous works (Awang et al., 2003a, 2003b; 2003c), we have reported the crystal structure of three organotin (IV) dithiocarbamate compounds which were prepared using in situ method. As a continuation of our interest in sulfur-containing ligands, we have synthesized a new series of organotin(IV) dithiocarbamate compounds using the same procedure. All these compounds have been characterized by elemental analyses, infrared spectra (IR) and Nuclear Magnetic Resonance (NMR) $\left({ }^{1} \mathrm{H}\right.$ and $\left.{ }^{13} \mathrm{C}\right)$. The crystal structure of compound 2 has been determined by X-ray diffraction study. In addition, the cytotoxic assay of the compounds obtained was screened against human hepatocarcinoma cells, HepG2 and the results are reported herein.

\section{MATERIALS AND METHODS}

All chemicals and solvents were of analytical grade. The N-benzylisopropylamine, dimethyltin(IV) chloride, dibutyltin(IV) chloride and triphenyltin(IV) chloride were purchased from Fluka while chloroform and ethanol were supplied by Merck. All the chemicals were used as supplied. Melting points were determined using an Electrothermal IA9100 instrument and elemental analysis with a Fison 1108 CHNS-O microanalyzer. Tin was determined gravimetrically by igniting a known quantity compound to $\mathrm{SnO}_{2}$. The infrared spectra were recorded on a Perkin Elmer FT-IR Model GX spectrophotometer using $\mathrm{KBr}$ discs in the range $4000-400 \mathrm{~cm}^{-1}$ and nujol in polyethylene for the wave number range between $400-250 \mathrm{~cm}^{-1}$. The ${ }^{1} \mathrm{H}$ and ${ }^{13} \mathrm{C}$ NMR spectra were recorded in $\mathrm{CDCl}_{3}$ on a Joel JNM-LA 400 spectrometer with TMS as the standard. Single crystal X-ray diffraction study was carried out using SMART APEX CCD diffractometer.

$\begin{aligned} & \text { Synthesis of organotin(IV) } \\ & \text { benzylisopropyldithiocarbamate } \\ & \text { compounds: }\end{aligned}$
Compound 1 was prepared by addition of $\mathrm{CS}_{2}\left(30 \times 10^{-3}\right.$
mol) to an ethanolic solution of $\mathrm{N}-$
benzylisopropylamine $\left(30 \times 10^{-3} \mathrm{~mol}\right)$ under stirring at
$5^{\circ} \mathrm{C}$. After one hour stirring, the addition of
dimethyltin(IV) dichloride $\left(15 \times 10^{-3} \mathrm{~mol}\right)$ yielded to a

white solution and still left stirring for another hour. A white solid was obtained and filtered off and then washed with cold ethanol and dried in vacuo. Recrystallization from a $\mathrm{CHCl}_{3}: \mathrm{C}_{2} \mathrm{H}_{5} \mathrm{OH}=1: 1(\mathrm{v}$ : v) mixture yielded colorless crystal. Compounds 2 and 3 were prepared by the same procedure, but dibutyltin(IV) dichloride $\left(15 \times 10^{-3} \mathrm{~mol}\right)$ or triphenyltin(IV) chloride $\left(30 \times 10^{-3} \mathrm{~mol}\right)$ was used. Compounds 1-3 were in white solid and highly soluble in chloroform. A general reaction scheme for the above preparation was given as below:

$\mathrm{R}_{\mathrm{m}} \mathrm{SnCl}_{\mathrm{m}-1}+\mathrm{nHN}\left(\mathrm{C}_{7} \mathrm{H}_{7}\right)\left(\mathrm{i}-\mathrm{C}_{3} \mathrm{H}_{7}\right)+\mathrm{nCS}_{2} \mathrm{EtOH} \rightarrow$ $\mathrm{R}_{\mathrm{m}} \mathrm{Sn}\left(\mathrm{S}_{2} \mathrm{CNR}{ }^{\prime} \mathrm{R}^{\prime}\right)_{\mathrm{n}}+\mathrm{nHCl}\left(\mathrm{m}=1, \mathrm{R}=\mathrm{C}_{6} \mathrm{H}_{5} ; \mathrm{m}=2, \mathrm{R}\right.$ $=\mathrm{CH}_{3}$ or $\mathrm{C}_{4} \mathrm{H}_{9}$ )

Crystallographic studies: A single crystal of compound 2 was mounted on glass fiber. Diffraction data were recorded on a Bruker SMART Apex system equipped with a graphite monochromatized Mo $\mathrm{K}_{\alpha}$ radiation $(\lambda=$ $0.71073 \AA$ ). . The data were collected using SMART (Siemens, 1996). The data integration was performed using SAINT (Siemens, 1996). An empirical absorption correction was carried out using SADABS (Sheldrick, 1996). The structure was solved with the direct methods and refined by full matrix least square methods based on $\mathrm{F}^{2}$, using the structure determination and graphics package SHEXTL (Sheldrick 1997a) based on SHELX 97 (Sheldrick, 1997b).

In vitro cytotoxic assay: The in vitro cytotoxic assay was carried out on human hepatocarcinoma cells line, HepG2. The cells were maintained in Eagle's Minimum Essential Medium (MEM) supplemented with $2 \mathrm{mM}$ of L-glutamine, $1 \mathrm{mM}$ of sodium pyruvate, $0.1 \mathrm{mM}$ of non-essential amino acid, $1.5 \mu \mathrm{g} \mathrm{mL} \mathrm{m}^{-1}$ sodium bicarbonate, $100 \mathrm{IU} \mathrm{mL}^{-1}$ penicillin and $100 \mu \mathrm{g} \mathrm{mL}^{-1}$ streptomycin. The cytotoxic assay was determined using the microtitration 3-(4,5-dimethylthiazol-2-yl)2,5-diphenyltetrazolium bromide (MTT) assay (Sheldrick, 1997b). The assay of each concentration for each compound was performed in triplicate. The fraction of surviving cells was measured relative to the untreated cell population by measuring the absorbance values at $570 \mathrm{~nm}$ with reference at $630 \mathrm{~nm}$ using an ELISA microplate reader (Bio Tek EL 340, USA). Cytotoxicity was expressed as $50 \%$ cytotoxic dose $\left(\mathrm{IC}_{50}\right)$, i.e., the concentration causing $50 \%$ inhibition of cell growth with reference to the control (untreated cells). The $\mathrm{IC}_{50}$ and the Standard Error of the Mean (SEM) were determined using Probit Analysis (SPSS, version 12). 


\section{RESULTS}

The synthesized compounds (1-3) are stable in the air, soluble in chloroform and dichloromethane. Elemental analysis and physical properties data are given in Table 1. The percentage of tin element in the compound was determined gravimetrically by igniting a known quantity of each compound to $\mathrm{SnO}_{2}$. The elemental analysis data of the compounds are in agreement with the general formula $\mathrm{R}_{\mathrm{m}} \mathrm{Sn}\left(\mathrm{S}_{2} \mathrm{CNR}{ }^{\prime} \mathrm{R}^{\prime \prime}\right)_{4-\mathrm{m}}\left(\mathrm{m}=3, \mathrm{R}=\mathrm{C}_{6} \mathrm{H}_{5}, \mathrm{R}\right.$ ' $=\mathrm{C}_{7} \mathrm{H}_{7}, \mathrm{R}$ " $=\mathrm{i}-\mathrm{C}_{3} \mathrm{H}_{7} ; \mathrm{m}=2, \mathrm{R}=\mathrm{CH}_{3}$ or $\mathrm{C}_{4} \mathrm{H}_{9} ; \mathrm{R}^{\prime}=\mathrm{C}_{7} \mathrm{H}_{7}, \mathrm{R}^{\prime \prime}=\mathrm{i}$ $\mathrm{C}_{3} \mathrm{H}_{7}$ ).

Infrared spectra: The important IR peaks of the compounds 1-3 were listed in Table 2. The type of bonding between the dithiocarbamate ligand and the tin atom was deduced using the $v_{\mathrm{C}-\mathrm{N}}$ and $v_{\mathrm{C}-\mathrm{S}}$ vibrations.

${ }^{1}$ H NMR spectra: The selected ${ }^{1} \mathrm{H}$ NMR chemical shifts of the compounds were given in Table 3 . The ${ }^{1} \mathrm{H}$ spectra of the compounds 1-3 were recorded in $\mathrm{CDCl}_{3}$. Table 4 showed the selected ${ }^{13} \mathrm{C}$ chemical shift data for compound 1-3. The ${ }^{13} \mathrm{C}$ NMR spectrum of the organotin(IV) benzylisopropyldithiocarbamate compounds exhibited a signal for methyl carbon of isopropyl group in the range 20.50-20.74 ppm while the chemical shift for carbon which directly attached to the $\mathrm{N}$ atom was found in the region 55.94-58.41 ppm. The important chemical shift of the carbon in dithiocarbamate compound was thione carbon $\left(\mathrm{NCS}_{2}\right)$. In compounds 1, 2 and 3, the chemical shift of $\mathrm{CS}_{2}$ were observed at 195.06, 202.65 and $198.43 \mathrm{ppm}$ respectively. The $\mathrm{CS}_{2}$ resonance for compounds 2 and 3 were shifted to downfield due to electron donating effect by the butyl and phenyl groups. The high value of thione carbon chemical shift could be explained by an increase of $\pi$-bond order in the whole $\mathrm{NCS}_{2}$ moiety (Nomura et al., 1989).

Crystal structure of $\left(\mathrm{C}_{4} \mathrm{H}_{9}\right)_{2} \mathrm{Sn}\left[\mathrm{S}_{2} \mathrm{CN}\left(\mathrm{C}_{7} \mathrm{H}_{7}\right)\left(\mathrm{i}-\mathrm{C}_{3} \mathrm{H}_{7}\right)\right]_{2}$ : Suitable crystals for $\mathrm{X}$-ray crystallographic studies of compound 2 were obtained by slow evaporation of a chloroform: Ethanol mixture at room temperature. The details of the crystal data and refinement parameters for compound 2 are listed in Table 5 while selected geometric parameters are listed in Table 6. The crystal structure of compound 2 shows that the tin atom has six coordination number (Fig. 1). The $\mathrm{IC}_{50}$ values for compounds 1-3 were given in Table 7.

\section{DISCUSSION}

Infrared spectra: Chatt et al. (1956) suggested resonance structures on the basis of an intense band in the region $1550-1480 \mathrm{~cm}^{-1}$ due to a C-N stretching vibration. Bradley and Gitlitz (1969) studied IR bands in several metal $\mathrm{N}, \mathrm{N}$-dialkyldithiocarbamates and reported the thioureide $(\mathrm{C}=\mathrm{\cdots})$ band near $1500 \mathrm{~cm}^{-1}$ as a characteristic for the $\left(\mathrm{S}_{2}\right) \mathrm{C}=\mathrm{NR}$ ' R" bond. We have observed $v(\mathrm{C}=\mathrm{N})$ band in the 1427-1444 $\mathrm{cm}^{-1}$ region, which matches well with the literature value. The observed $v_{\mathrm{C}-\mathrm{N}}$ vibrations lie between the range for C-N single bonds $\left(1250-1360 \mathrm{~cm}^{-1}\right)$ and C-N double bonds $\left(1640-1690 \mathrm{~cm}^{-1}\right)$. This suggests that the $\mathrm{C}=\mathrm{N}$ bonds have some partial double bond character. Another strong band in the $1148-1165 \mathrm{~cm}^{-1}$ may be attributed to $\mathrm{N}-\mathrm{C}_{2}$ for all of the compounds. Strong bands at 953-997 $\mathrm{cm}^{-1}$ were due to $v(\mathrm{C}=\mathrm{S})$ bond of the chelating character of the dithiocarbamate ligand in all cases (Bonati and Ugo, 1967). Besides this, far IR spectra of the compounds showed a band in the region of $355-377 \mathrm{~cm}^{-1}$ was assigned to $\mu(\mathrm{Sn}-\mathrm{S})$ stretching vibration. Thus lending support to the proposed coordination in the compounds (Soliman and Mohamed, 2004).

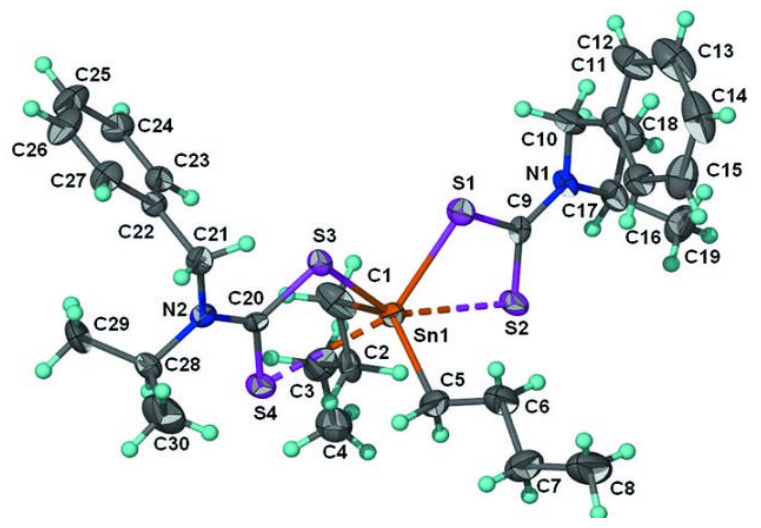

Fig 1: ORTEP plot of compound 2 at $50 \%$ probability level

Table 1: Physical and elemental analysis data of organotin(IV) N-benzyl-N-isopropyl dithiocarbamate compounds

\begin{tabular}{|c|c|c|c|c|c|c|c|c|}
\hline \multirow[b]{2}{*}{ Molecular formula } & \multirow[b]{2}{*}{ Color } & \multirow[b]{2}{*}{ Yield (\%) } & \multirow[b]{2}{*}{ Melting point $\left({ }^{\circ} \mathrm{C}\right)$} & \multicolumn{5}{|c|}{ Found (calculated) (\%) } \\
\hline & & & & $\mathrm{C}$ & $\mathrm{H}$ & $\mathrm{N}$ & S & $\mathrm{Sn}$ \\
\hline$\left(\mathrm{CH}_{3}\right)_{2} \mathrm{Sn}\left[\mathrm{S}_{2} \mathrm{CN}\left(\mathrm{C}_{7} \mathrm{H}_{7}\right)\left(\mathrm{iC}_{3} \mathrm{H}_{7}\right)\right]_{2}$ & Colorless & 83 & $132.1-133.7$ & $47.88(48.24)$ & $5.70(5.74)$ & $4.48(4.69)$ & $19.31(21.47)$ & $20.35(19.86)$ \\
\hline$\left(\mathrm{C}_{4} \mathrm{H}_{9}\right)_{2} \mathrm{Sn}\left[\mathrm{S}_{2} \mathrm{CN}\left(\mathrm{C}_{7} \mathrm{H}_{7}\right)\left(\mathrm{iC}_{3} \mathrm{H}_{7}\right)\right]_{2}(2)$ & Colorless & 79 & $111.1-112.8$ & $53.09(52.86)$ & $6.26(6.80)$ & $4.03(4.11)$ & $16.48(18.82)$ & $18.87(17.41)$ \\
\hline$\left(\mathrm{C}_{6} \mathrm{H}_{5}\right)_{3} \mathrm{Sn}\left[\mathrm{S}_{2} \mathrm{CN}\left(\mathrm{C}_{7} \mathrm{H}_{7}\right)\left(\mathrm{iC}_{3} \mathrm{H}_{7}\right)\right]$ & Colorless & 76 & $128.1-130.2$ & $60.53(60.64)$ & $4.88(5.04)$ & $2.21(2.44)$ & $10.11(11.16)$ & $21.29(20.72)$ \\
\hline
\end{tabular}


Am. J. Applied Sci., 7 (8): 1047-1052, 2010

Table 2: The important infrared absorption bands $\left(\mathrm{cm}^{-1}\right)$

\begin{tabular}{|c|c|c|c|c|c|}
\hline \multirow[b]{2}{*}{ Compound } & \multicolumn{5}{|c|}{ Frequency $\left(\mathrm{cm}^{-1}\right)$} \\
\hline & $v(\mathrm{C}-\mathrm{H})$ & $v(\mathrm{C}=\mathrm{N})$ & $v(\mathrm{~N}-\mathrm{C})$ & $v(C \stackrel{\cdots}{-\cdots})$ & $v(\mathrm{Sn}-\mathrm{S})$ \\
\hline 1 & 2978 & 1444 & 1148 & 997 & 377 \\
\hline 2 & 2969 & 1427 & 1165 & 956 & 355 \\
\hline 3 & 2954 & 1443 & 1162 & 953 & 356 \\
\hline
\end{tabular}

Table 3: Selected ${ }^{1} \mathrm{H}$ NMR spectra data of compounds 1-3 ( $\delta$, ppm)

\begin{tabular}{lllll}
\hline & Chemical shift, $\delta(\mathrm{ppm})$ & \\
\cline { 2 - 5 } Compound & $\mathrm{CH}_{\text {aromatic }}$ & $-\mathrm{NCH}$ & $-\mathrm{NCH}_{2}$ & $-\mathrm{CH}_{3}$ \\
\hline Benzylisopropylamine & $7.17-7.30$ & 2.79 & 3.71 & $1.07(1.05)$ \\
1 & $7.36-7.49$ & 5.10 & 5.07 & $1.26(1.24)$ \\
2 & $7.23-7.29$ & 5.47 & 5.16 & $1.18(1.16)$ \\
3 & $7.26-7.39$ & 5.35 & 5.10 & $1.18(1.16)$ \\
\hline
\end{tabular}

Table 4: The selected ${ }^{13} \mathrm{C}$ NMR spectra data of compounds 1-3 ( $\delta$, ppm)

\begin{tabular}{llrrr}
\hline & Chemical shift $(\delta, \mathrm{ppm})$ & & \\
\cline { 2 - 5 } Compound & $\mathrm{NCS}_{2}$ & $-\mathrm{C}_{6} \mathrm{H}_{5}$ & $-\mathrm{NCH}_{2}$ & $\mathrm{i}-\mathrm{C}_{3} \mathrm{H}_{7}$ \\
\hline 1 & 195.06 & 135.95 & 130.29 & 128.95 \\
& 128.22 & 58.41 & 57.37 & 20.50 \\
2 & 202.65 & 137.13 & 128.58 & 127.13 \\
& 126.69 & 55.94 & 51.56 & 20.64 \\
3 & 198.43 & 136.90 & 129.26 & 128.69 \\
& 126.65 & 57.89 & 52.79 & 20.74 \\
\hline
\end{tabular}

${ }^{1}$ H NMR spectra: The results were compared with the benzylisopropylamine which used as the starting material to prepare these compounds. A number of signals have been observed on complexation shifts from their original position. A downfield shift in the resonance signals of the compounds in comparison to the starting material was due to bonding between the dithiocarbamate ligand to the tin metal. The aromatic proton signals, which appear in the form of a complex multiplet at $\delta 7.17-7.30 \mathrm{ppm}$, shifts to $\delta 7.23-7.49 \mathrm{ppm}$ due to deshielding on complexation. These results were in agreement as reported by Domazetis et al. (1977) at 7.15-7.60 ppm.

Crystal structure of $\left(\mathrm{C}_{4} \mathrm{H}_{9}\right)_{2} \mathrm{Sn}\left[\mathrm{S}_{2} \mathrm{CN}\left(\mathrm{C}_{7} \mathrm{H}_{7}\right)(\mathrm{i}\right.$ $\left.\left.\mathbf{C}_{3} \mathbf{H}_{7}\right)\right]_{2}$ : The Sn-S bonds ( $\mathrm{Sn}(1)-\mathrm{S}(1) 2.529(1) \AA$ and $\mathrm{Sn}(1)-\mathrm{S}(2) 2.887(1) \AA$ ) lies closely to the analogues complex $\mathrm{Bu}_{2} \mathrm{Sn}\left[\mathrm{S}_{2} \mathrm{CNC}_{6} \mathrm{H}_{12}\right]_{2}$ (Rehman et al., 2006). Thus shorter bond length was closed to the sum of the covalent radii of tin and sulphur $(2.42 \AA)$ (Shahzadi et al., 2008). The bond distances of $\mathrm{S}(2)$ and S(4) with Sn were at 2.887(1) and 3.031(1) A respectively, which were too long to be strong covalent bonds. However, these Sn-S distances were shorter than the sum of the van der Waals radii $(4.0 \AA)$ for these atoms. Thus, these bonds may be considered weak. There were two important reasons for this: first, the strong electron-withdrawing nature of isopropyl, $\mathrm{i}-\mathrm{C}_{3} \mathrm{H}_{7}$ will decreases the electron density on the $\mathrm{S}$ atom at C-S and reduces its ability to coordinate to the tin atom.
Table 5: Crystallographic data and refinement parameters for compound 2

\begin{tabular}{|c|c|}
\hline Compound & 2 \\
\hline Chemical formula & $\mathrm{Sn}\left(\mathrm{C}_{4} \mathrm{H}_{9}\right)_{2}\left(\mathrm{C}_{11} \mathrm{H}_{14} \mathrm{NS}_{2}\right)_{2}$ \\
\hline Formula weight & 681.62 \\
\hline Crystal system & Triclinic \\
\hline Space group & P1 \\
\hline $\mathrm{a}(\AA)$ & $17.7745(2)$ \\
\hline $\mathrm{b}(\AA)$ & $19.5463(3)$ \\
\hline c $(\AA)$ & $26.2062(4)$ \\
\hline$\alpha\left({ }^{\circ}\right)$ & $102.5254(7)$ \\
\hline$\beta\left({ }^{\circ}\right)$ & $95.1492(7)$ \\
\hline$\gamma\left(\left(^{\circ}\right)\right.$ & $110.2569(8)$ \\
\hline $\mathrm{V}\left(\AA^{3}\right)$ & $8202.1(2)$ \\
\hline $\operatorname{Mo~K} \alpha(\AA)$ & 0.71073 \\
\hline $\mathrm{Z}$ & 10 \\
\hline $\mathrm{D} / \mathrm{Mgm}^{-3}$ & 1.380 \\
\hline$\mu\left(\mathrm{mm}^{-1}\right)$ & $1.06 \mathrm{~mm}^{-1}$ \\
\hline $\mathrm{F}(000)$ & 3540 \\
\hline Color & Colorless \\
\hline Crystal size (mm) & $0.3 \times 0.3 \times 0.1 \mathrm{~mm}$ \\
\hline Temperature (K) & 123 \\
\hline$\theta$ range $\left(^{\circ}\right)$ & $2.2-28.3$ \\
\hline Index ranges $( \pm \mathrm{h}, \pm \mathrm{k}, \pm \mathrm{l})$ & $-23 / 23,-24 / 25,-32 / 34$ \\
\hline Total no. reflections collected & 23409 \\
\hline Independent reflections & $36923\left[\mathrm{R}_{\mathrm{int}}=0.028\right]$ \\
\hline No. of data used for refinement & 36923 \\
\hline No. of parameter refined & 96 \\
\hline Largest and smallest peak $\left(\mathrm{e} \AA^{-3}\right)$ & 2.53 and -1.45 \\
\hline
\end{tabular}

Table 6: Selected bond lengths $(\AA)$ and bond angles $\left({ }^{\circ}\right)$ for compound 2

\begin{tabular}{|c|c|c|c|}
\hline Bond length $(\AA)$ & Bond ang & & \\
\hline $\operatorname{Sn}(1)-C(1)$ & $2.141(5)$ & $C(1)-\operatorname{Sn}(1)-C(5)$ & $129.0(2)$ \\
\hline $\operatorname{Sn}(1)-C(5)$ & $2.146(4)$ & $\mathrm{C}(1)-\mathrm{Sn}(1)-\mathrm{S}(1)$ & $108.14(1)$ \\
\hline $\mathrm{Sn}(1)-\mathrm{S}(1)$ & $2.529(1)$ & $\mathrm{C}(5)-\operatorname{Sn}(1)-\mathrm{S}(1)$ & $115.24(11)$ \\
\hline $\operatorname{Sn}(1)-S(2)$ & $2.887(1)$ & $\mathrm{C}(1)-\mathrm{Sn}(1)-\mathrm{S}(3)$ & $105.81(13)$ \\
\hline $\mathrm{Sn}(1)-\mathrm{S}(3)$ & $2.536(1)$ & $\mathrm{C}(5)-\mathrm{Sn}(1)-\mathrm{S}(3)$ & $106.94(13)$ \\
\hline $\operatorname{Sn}(1)-S(4)$ & $3.031(1)$ & $\mathrm{S}(1)-\mathrm{Sn}(1)-\mathrm{S}(3)$ & 79.95(3) \\
\hline$S(1)-C(9)$ & $1.757(4)$ & $\mathrm{C}(1)-\mathrm{Sn}(1)-\mathrm{S}(2)$ & $86.46(13)$ \\
\hline$S(2)-C(9)$ & $1.686(4)$ & $\mathrm{C}(5)-\mathrm{Sn}(1)-\mathrm{S}(2)$ & $87.93(11)$ \\
\hline $\mathrm{S}(3)-\mathrm{C}(20)$ & $1.738(4)$ & $\mathrm{S}(1)-\mathrm{Sn}(1)-\mathrm{S}(2)$ & $65.65(3)$ \\
\hline$S(4)-C(20)$ & $1.695(4)$ & $\mathrm{S}(3)-\mathrm{Sn}(1)-\mathrm{S}(2)$ & $145.60(3)$ \\
\hline $\mathrm{N}(1)-\mathrm{C}(9)$ & $1.342(5)$ & C(1)-Sn(1)-S(4) & $80.36(12)$ \\
\hline $\mathrm{N}(2)-\mathrm{C}(20)$ & $1.351(5)$ & $\mathrm{C}(5)-\mathrm{Sn}(1)-\mathrm{S}(4)$ & $80.46(11)$ \\
\hline $\mathrm{N}(1)-\mathrm{C}(10)$ & $1.469(5)$ & $\mathrm{C}(2)-\mathrm{C}(1)-\mathrm{Sn}(1)$ & $102.3(3)$ \\
\hline $\mathrm{N}(1)-\mathrm{C}(17)$ & $1.491(5)$ & $C(3)-C(2)-C(1)$ & $111.9(5)$ \\
\hline $\mathrm{N}(2)-\mathrm{C}(21)$ & $1.469(5)$ & $C(6)-C(5)-S n(1)$ & $119.0(3)$ \\
\hline $\mathrm{N}(2)-\mathrm{C}(28)$ & $1.488(5)$ & $\mathrm{C}(7)-\mathrm{C}(6)-\mathrm{C}(5)$ & $112.9(3)$ \\
\hline
\end{tabular}

Table 7: Cytotoxic assays, $\mathrm{IC}_{50}$ of compounds 1-3

\begin{tabular}{ll}
\hline & $\mathrm{IC}_{50}\left(\mu \mathrm{g} \mathrm{mL} L^{-1}\right)$ \\
Compounds & Human hepatocarcinoma cells, HepG2 \\
\hline 1 & Inactive \\
2 & $4.771 \pm 0.601$ \\
3 & $1.435 \pm 0.667$ \\
Etoposide & $0.600 \pm 0.130$
\end{tabular}

$\mathrm{IC}_{50}\left(\mu \mathrm{g} \mathrm{mL}^{-1}\right)$ : The concentration that yields $50 \%$ inhibition of the cell compared with untreated control. The cytotoxicity values are expressed as mean \pm SEM from the triplicate. Reference drug $=$ Etoposide

Second, the steric interaction of the two bulky butyl groups and four-membered chelating ring may be 
prevented the formation of the $\mathrm{Sn}(1)-\mathrm{S}(2)$ and $\mathrm{Sn}(1)$ $\mathrm{S}(4)$ bonds. The $\mathrm{C}(1)-\mathrm{Sn}(1)-\mathrm{C}(5)$ linkage was not linear, having an angle of $129.0(2)^{\circ}$, which was much smaller than the value expected for a regular bipyramidal. The $\mathrm{Sn}$ atom exists in a tetrahedral $\mathrm{C}_{2} \mathrm{~S}_{2} \mathrm{Sn}$ coordination geometry. The best coordination geometry described as distorted towards skew-trapezoidalbipyramidal owing to the proximity of the doublebonded $\mathrm{S}$ atoms.

From the data in Table 7, it was found that compound 1 was inactive against HepG2 cells compared to compounds 2 and 3. Compound 3 showed a significant cytotoxic activity with a lower $\mathrm{IC}_{50}$ value of $1.435 \mu \mathrm{g} \mathrm{mL}^{-1}$ compared to compound 2 (4.771 $\mu \mathrm{g}$ $\mathrm{mL}^{-1}$ ). This was due to compound 3 was derived from triphenyltin(IV) (triorganotin(IV)) which was more active compared to the diorganotin(IV) (compounds 2). Hence, the cytotoxic activity of organotin(IV) obtained in this study could be arranged as: triorganotin(IV) > diorganotin(IV).

\section{CONCLUSION}

A new series of organotin(IV) dithiocarbamate compounds has been successfully synthesized and characterized. Elemental analysis C, H, N, S and Sn data obtained were in agreement with the predicted formula. The spectroscopic data supported by crystallographic data indicates that the dithiocarbamate groups form bidentate chelates with the organotin(IV) moieties. The crystallographic information obtained for the dibutyltin(IV) benzylisopropyldithiocarbamate clearly showed that the benzylisopropyldithiocarbamate ligand did indeed chelate as a bidentate entity. The bidentate chelation was unequivalent as demonstrated by the Sn-S bond distances. Based on the cytotoxic activity, compound 3 showed significant cytotoxic activity compared to compound 2 but slightly lower compared to the reference drug and believed to possess a significant role in the medicinal area in the future.

\section{ACKNOWLEDGEMENT}

The researcher would like to thank the School of Chemical Sciences and Food Technology, Faculty of Science and Technology for support and the provision of laboratory facilities. We also like to thank Higher Education Ministry, Malaysia for the financial support under the research grant UKM-NN-FRGS0003-2007 and Prof. Ng Seik Weng from Chemistry Department, University of Malaya for crystallographic studies.

\section{REFERENCES}

Awang, N., I. Baba, M.M.S. Yusof and B.M. Yamin, 2003a. Bis(N-cyclohexyl-Nmethyldithiocarbamato) dimethyltin(IV). Acta Crystallogr. E, 59: 348-349. DOI: 10.1107/S1600536803010420

Awang, N., I. Baba, M.M.S. Yusof and B.M. Yamin, 2003b. (N-cyclohexyl-N-methyldithiocarbamato) triphenyltin(IV). Acta Crystallogr. E, 59: 414-415. DOI: 10.1107/S1600536803011991

Awang, N., I. Baba, M.M.S. Yusof and B.M. Yamin, 2003c. (N-cyclohexyl-N-ethyldithiocarbamato) triphenyltin(IV). Acta Crystallogr. E, 59: 594-595. DOI: $10.1107 / \mathrm{S} 1600536803015277$

Bonati, F. and R. Ugo, 1967. Organotin(IV) N,Ndisubstituted dithiocarbamates. J. Organomet. Chem., 10: 257-268. DOI: 10.1016/S0022328X(00)93085-7

Bradley, D.C. and M.H. Gitlitz, 1969. Preparation and properties of NN-dialkyldithiocarbamates of early transition elements. J. Chem. Soc. A, 84: 1152-1156. DOI: $10.1039 / \mathrm{J} 19690001152$

Chatt, J., L.A. Duncanson and L.M. Venanzi, 1956. Electronic structure of dithiocarbamate and xanthates. Nature, 177: 1042-1043. DOI: 10.1038/1771042b0

Crouse, K.A., K.B. Chew, M.T.H. Tarafder, A. Kasbollah and A.M. Ali, 2004. Synthesis, Characterization and Bio-activity of S-2-Picolyldithiocarbazate (S2PDTC), some of its Schiff bases and their Ni(II) complexes and $\mathrm{x}$-ray structure of S-2-picolyl- $\beta-\mathrm{N}$ (2-acetylpyrrole)dithiocarbazate. Polyhedron, 23: 161168. DOI: $10.1016 /$ j.poly.2003.09.025

Domazetis, G., R.J. Magee and B.D. James, 1977. Synthesis and structure of some triphenyltin(IV) dithiocarbamate compounds. J. Organomet. Chem., 141: 57-69. DOI: 10.1016/S0022-328X(00)90667-3

Gielen, M., 1996. Tin-based antitumour drugs. Coord. Chem. Rev., 151: 41-51. DOI: 10.1016/S00108545(96)90193-9

Gielen, M., M.D.V. Biesemans and R. Willem, 2000. Synthesis, characterization and in vitro antitumor activity of $\mathrm{di}^{-}$and triorganotin derivatives of polyoxa- and biologically relevant carboxylic acids. J. Inorg. Biochem., 79: 139-145. DOI: 10.1016/S0162-0134(99)00161-0

Jamil, K., M. Bakhtiar, A.R. Khan, F. Rubina and R. Wajid et al., 2009. Synthesis characterization and antimicrobial activities of noval organotin compounds. Afr. J. Pure Applied Chem., 3: 66-71. http://www.academicjournals.org/AJPAC/PDF/pdf 2009/April/Jamil\%20et\%20al.pdf 
Khan, S.R.A., S. Huang, S. Shamsuddin, S. Inutsuka and K.H. Whitmire, 2000. Synthesis, characterization and cytotoxicity of new platinum(IV) axial carboxylate complexes: Crystal structure of potential antitumor agent $\left[\mathrm{Pt}^{\mathrm{IV}}(\right.$ trans1R,2R-diaminocyclohexane)trans(acetate $)_{2} \mathrm{Cl}_{2}$ ] . Bioorg. Med. Chem., 8: 515-521. DOI: 10.1016/S0968-0896(99)00313-2

Mansouri-Torshizi, H., M. Saeidifar, A. Divsalar and A.A. Sabour, 2010. Spectrochimica acta part A: Molecular and biomolecular spectroscopy. Spectrochimica Acta Part A, 77: 312-318. DOI: 10.1016/j.saa.2010.05.029

Nomura, R., S. Fujii, A. Takabe and H. Matsuda, 1989. Preparation of novel metal dithiocarbamate complexes containing $\omega-\mathrm{OH}$ group. Stabilization effect of the $\mathrm{OH}$ group on the $\mathrm{HNCS}_{2}$-Mt linkage. Polyhedron, 8: 1891-1896. DOI: 10.1016/S02775387(00)86410-4

Novelli, F., M. Recine, F. Sparatore and C. Juliano, 1999. Triorganotin compounds as antimicrobial agents. IL Farmaco, 54: 237-241. DOI: 10.1016/S0014-827X(99)00020-8

Rehman, Z., S. Shahzadi, S. Ali, A. Badshah and G.X. Jin, 2006. Crystal structure of 1,1-dibutyl-1,1bis[(4-methyl-1-piperidinyl) dithiocarbamato)] tin(IV). J. Iran. Chem. Soc., 3: 157-160.
Sheldrick, G.M., 1996. SADABS, program for empirical absorption correction of area detector data. University of Göttingen.

Sheldrick, G.M., 1997a. SHELXTL V5 1 software reference manual. Bruker AXS Inc.

Sheldrick, G.M., 1997b. SHELX97 programs for crystal structure analysis. University of Gottingen, Germany.

Siemens, S., 1996. SMART and SAINT area detector control and integration software. Siemens Analytical X-Ray Systems Inc.

Soliman, A.A. and G.G. Mohamed, 2004. Study of the ternary complexes of copper with salicylidene-2aminothiophenol and some amino acids in the solid state. Thermochimica Acta, 421: 151-159. DOI: 10.1016/j.tca.2004.03.010

Shahzadi, S., S. Ali and M. Fettouhi, 2008. Synthesis, spectroscopy, in vitro biological activity and X-ray structure of (4-Methylpiperidine-dithiocarbamatoS, S')triphenyltin(IV). J. Chem. Crystallogr., 38: 273-278. DOI: $10.1007 / \mathrm{s} 10870-007-9295-5$ 